Buca Eğitim Fakültesi Dergisi,

2021, Say1 51, s. 327-344

Araştırma Makalesi

\title{
Üniversite Öğrencilerinde Kişiler Arası Duygu Düzenlemenin Yordayıcıları Olarak Öz Denetim ve Temel Psikolojik İhtiyaç Doyumu
}

\section{Self-Control and Basic Psychological Need Satisfaction as the Predictors of Interpersonal Emotion Regulation Among University Students}

\author{
Samiye OGAN ${ }^{I}$, Fatma Selda ÖZ SOYSAL ${ }^{2}$
}

\begin{abstract}
${ }^{1}$ Sorumlu Yazar, Yüksek Lisans Öğrencisi, Ĕ̆itim Bilimleri Bölümü, Eğitim Fakültesi, Dokuz Eylül Üniversitesi, Türkiye, samiyeogan.1502@gmail.com, (https://orcid.org/0000-0003-40640371)

${ }^{2}$ Doç. Dr., Eğitim Bilimleri Bölümü, Eğitim Fakültesi, Dokuz Eylül Üniversitesi, Türkiye, seldaoz.oz@gmail.com, (https://orcid.org/0000-0001-5406-7786)
\end{abstract}

Geliş Tarihi: $31 / 01 / 2021$

Kabul Tarihi:28/04/2021

\section{ÖZ}

Bu çalışmanın amacı üniversite öğrencilerinin öz denetim ve temel psikolojik ihtiyaç doyum düzeylerinin, kişiler arası duygu düzenlemelerini yordama gücünü belirlemektir. Araştırmanın çalışma grubunu, 20202021 eğitim-öğretim yılında Dokuz Eylül Üniversitesi Buca Eğitim Fakültesi’nin farklı bölümlerinde öğrenimlerine devam eden 246'sı kadın $(\% 60,2)$ ve 162'si $(\% 39,8)$ erkek olmak üzere toplam 408 üniversite öğrencisi oluşturmaktadır. Katılımcıların yaşları 18-26 yaş ( $\bar{X}=21.13)$ arasında değişiklik göstermektedir. Araştırmada veri toplama aracı olarak "Kişiler arası Duygu Düzenleme Ölçeğì" (Gökdağ, Sorias, Kıran ve Ger, 2019), "Öz Denetim Ölçeği” (Duyan ve diğerleri, 2012), "İhtiyaç Doyumu Ölçeği" (Bacanlı ve Cihangir-Çankaya, 2003) ve kişisel bilgi formu kullanılmıştır. Verilerin analizinde, aşamalı regresyon (stepwise) analiz yöntemi kullanılmıştır. Aşamalı regresyon analizi sonucunda elde edilen bulgular, öz denetimin ve temel psikolojik ihtiyaç doyumunun kişiler arası duygu düzenlemeye ilişkin varyansın \%42.9'unu açıkladığını ortaya koymaktadır. Analiz sonuçları incelendiğinde, kişiler arası duygu düzenleme değişkeninin en güçlü yordayıcısının İhtiyaç Doyumu Ölçeği'nin alt boyutu olan ilişkili olma değişkeni olduğu, bu değişkenini sırasıyla öz denetim, yeterlik ve özerklik değişkenlerinin izlediği gözlemlenmektedir. Sonuç olarak, üniversite öğrencilerinin öz denetim ve kişiler arası duygu düzenleme becerilerinin geliştirilmesine yönelik psiko-eğitim programlarının geliştirilmesi ve uygulanması önerilmektedir.

Anahtar Kelimeler: Kişiler arası duygu düzenleme, öz denetim, temel psikolojik ihtiyaç doyumu, üniversite öğrencileri.

\begin{abstract}
The aim of this study is; to determine the predictive power of university students' self-control and basic psychological need satisfaction levels on interpersonal emotion regulation. The study group of the research consists of the 408 university students, 246 women (60.2\%) and 162 (39.8\%) men, who continue their education in different departments of Dokuz Eylül University Buca Faculty of Education in the 2020-2021 academic year. Participants' ages vary between $18-26$ years $(=21.13)$. Research data were collected by the Interpersonal Emotion Regulation Questionnaire, Self-Control Scale, Basic Psychological Need Satisfaction Scale and personal information form. The stepwise analysis method was used for data analysis. The findings obtained as a result of stepwise regression analysis reveal that self-control and basic psychological need satisfaction explain $42.9 \%$ of the variance related to interpersonal emotion regulation.
\end{abstract}


When the analysis results are examined, it is observed that the strongest predictor of the interpersonal emotion regulation variable is the relatedness, which is the sub-dimension of the Basic Psychological Need Satisfaction Scale, followed by the variables of self-control, competence and autonomy. As a result, it is recommended to develop and implement psycho-education programs aimed at improving the self-control and interpersonal emotion regulation skills of university students.

Keywords: Interpersonal emotion regulation, self-control, basic psychological need satisfaction, university students.

\section{GİRIŞ}

Bireyler, yaşamları boyunca gerek sözlü gerek sözlü olmayan yöntemler ile duygu, düşünce ve davranışlarını ifade etme ihtiyacı içerisinde olmaktadırlar. Duyguların karmaşık bir yapıya sahip olması; tanımlanabilmesini, anlaşılabilmesini ve duyguları ifade etme ihtiyacının giderilmesini zorlaştırmaktadır. Mayer, Salovey ve Caruso (2000) duyguyu, "bireylerin sosyal çevresinde karşılaştıkları durumlara yönelik verdikleri fizyolojik, biyolojik ve bilişsel öğeler barındıran tepkiler" olarak tanımlamaktadır.

Duygular, kişiler arası ilişkilerin temelini oluşturmakta ve günlük yaşantının merkezinde yer almaktadır. Bireysel farklılıklar ve geçmiş yaşantılar, benzer yaşantılara farklı duyguyla karşılık verilmesinde etkin rol almaktadır. Dolayısıyla duygular, yaşam süresince farklılaşmakta ve zenginleşmektedir. Duygular, bireylerin olayları algılama, yorumlama ve anlamlandırma biçimlerini etkileyebilmektedir (Yarkın, 2014). Günlük yaşamda deneyimlediğimiz duygular olumlu, uyumlu ve olumsuz/rahatsızlık verici bir biçimde kendini gösterebilmektedir. Duyguların işlevsel bir biçimde, uygun zamanda ve yoğunlukta ifade edilememesi hâlinde bireyin günlük yaşantısı ve kişiler arası ilişkileri oldukça zorlaşmaktadır. Duyguların işlevsel bir biçimde ifade edilebilmesi ise duyguları düzenleyebilme becerisi ile mümkün olabilmektedir. Duyguları deneyimlemek ve düzenlemek, temel insani nitelikler arasında yer almaktadır. Duygu düzenleme, bireylerin hangi duyguları nasıl ve ne zaman deneyimlediklerini, bu duyguları nasıl ifade ettiklerini içeren bir sürece odaklanmaktadır (Gross, 1998). Duygu düzenleme süreci ilk olarak anne ile kurulan bağ aracıllğı ile gerçekleştirilirken, bu süreç ilerleyen gelişim dönemlerinde yakın ilişkiler geliştirilmesiyle birlikte çeşitlilik göstermektedir (Thompson, 1994). Bu kapsamda duygu düzenleme kaynaklarının, içinde bulunulan sosyal çevre ve erken çocukluktaki bağlanma deneyimleri ile birlikte şekillendiği söylenebilmektedir (Hofman, Carpenter ve Curtiss, 2016). Duygu düzenleme, bireylerin mevcut duruma uyum sağlamak için duygu ifadelerini değiştirme kapasiteleri olarak da kavramsallaştırılmaktadır (Gross, 2015). Duygu düzenleme kavramı, duyguların gözlenmesinden, değerlendirilmesinden ve değiştirilmesinden sorumlu içsel veya dışsal süreçleri ifade etmektedir (Thompson, 1994). İçsel süreçler, bireyin kendi duygularını kişiler arası ilişkiler aracılı̆̆ ile düzenleme süreci iken; dışsal süreçler, başkalarının duygularını düzenleme sürecini ifade etmektedir (Dixon Gordon, Haliczer, Conkey ve Whalen, 2018). İçsel süreçlerin sağlanmasında, "yeniden çerçevelendirme" yöntemi etkili olurken; dışsal süreçlerin sağlanmasında, 'destek' ve 'onaylama' gibi davranış örüntüleri etkili olmaktadır (Niven, Garcia, van der Löwe, Holman ve Mansel, 2015). Duygu düzenleme, duyguların yoğunluğunu azaltmaya ve/veya artırmaya yönelik bir çabayı ifade etmekte olup başa çıkma, sadece olumsuz duyguların yoğunluğunu azaltmaya yönelik bir çabayı içermektedir (Bosse, Pontier ve Treur, 2010). Zaki ve Williams (2013) duygu düzenlemenin sosyal boyutuna dikkat çekmekte ve bireyin duygularını, sosyal etkileşim aracılığ ile düzenlemesi kişiler arası duygu düzenleme (Hofmann ve diğ., 2016) kavramı ile ele alınmaktadır. Bununla birlikte, stresli yaşantılara yönelik sergilenen duygusal tepkilerin, sosyal ilişkiler çerçevesinde düzenlenmesini içeren bir süreci de kapsamaktadır. Böylelikle kişiler arası ilişkilerde rahatsızlık verici duygular yerini memnuniyet verici duygulara bırakmaktadır. Kişiler arası duygu düzenleme kavramı, başka bir bireyin varlığı ile birlikte olumsuz duyguların azaltılmasına olanak tanımakta (Coan, 2011) ve siklıkla sosyal destek kavramı (Gross ve John, 2003; Marroquín, 2011) ile birlikte ele alınmaktadır. Bu bağlamda düşük sosyal destek düzeyine sahip bireylerin, duygularını düzenlemede güçlük çektikleri ifade 
edilmektedir (Gross ve John, 2003; Tatnell, Kelada, Hasking ve Martin, 2014). Ayrıca ilgili alan yazında kișiler arası duygu düzenleme becerisinin, duyarlılık (Lopes, Salovey, Côté, Beers ve Petty, 2005) ve empati (Williams, Morelli, Ong ve Zaki, 2018; Zaki, 2020) kavramları ile ilişkilendirildiği de gözlemlenmektedir.

Duygu düzenleme sürecinin daha iyi anlaşılabilmesi, davranışın altında yatan mekanizmalara yönelik bilgi edinilmesiyle mümkün olabilmektedir. Tam bu noktada özdenetim kavramı ortaya çıkmaktadır. Kişiler arası ilişkilerde, duyguların ifade edilebilmesi ve düzenlenebilmesi davranış biçimlerine göre farklılık gösterebilmektedir. Bireylerin davranışlarını değiştirebilme (Tangney, Baumeister ve Boone, 2004) ve uyarlayabilme (Duyan, Gülden ve Gelbal, 2012) becerisi olarak tanımlanan öz denetim kavramı, etkili kişiler arası ilişkilerin kurulabilmesinde oldukça kritik bir rol üstlenmektedir. Öz denetim; davranışların sorumluluğunun alınabilmesini (Rosenbaum, 1993), davranışsal kontrolün sağlanabilmesini (Tangney ve diğ., 2004), yıkıcı duyguların ve güdülerin kontrol altına alınabilmesini (Goleman, 2000) içermektedir. Öz denetimin; onarıcı, yenileyici ve yaşantısal öz denetim olmak üzere üç boyutu yer almaktadır. Onarıcı öz denetim, olumsuz duygu durumlarla baş edebilmeyi; yenileyici öz denetim, dengeyi sağlamak adına sergilenecek düzenleyici davranışları; yaşantısal öz denetim ise açık olunan yeni yaşantıları içermektedir. Bireylerin öz denetim düzeyleri ise bu boyutların karşılanma düzeyleriyle şekillenmektedir. Öz denetimi yüksek bireylerin, daha uyumlu bir yapıya sahip oldukları (MacDonald, 1995) ve daha etkili sosyal ilişkiler kurdukları (Baumeister ve Alquist, 2009; Tangney ve diğerleri, 2004) gözlemlenmektedir. Ayrıca öz denetimin; benlik saygısı, güvenli bağlanma, kişiler arası beceriler, olumlu duygular ile ilişkili olduğu da belirtilmektedir (Tangney ve diğerleri, 2004). Öz denetimi düşük bireylerin ise duyarsız oldukları (DeLisi ve diğ., 2010), dürtü kontrolünde problem yaşadıkları (Friese ve Hofmann, 2009; Johnson ve Ostendorf, 1993) ve bağımlılık eğilimi gösterdikleri (Kızıltaş, 2019; Kim ve Lee, 2012; Akkuş Çutuk, 2020) ifade edilmektedir. Bu kapsamda öz denetim becerisinin, dürtü kontrolünü sağladığı, dolayısıyla temel ihtiyaçların karşılanma düzeyini etkilediği söylenebilmektedir.

Bireyler, duygularını ve davranışlarını temel psikolojik ihtiyaçlarına göre şekillendirebilmektedir. Temel psikolojik ihtiyaçların giderilmemesi, ruh sağlı̆ını olumsuz yönde etkilemekte (Glasser, 1965) ve kişilerin ihtiyaçlarını karşılayacak hedeflere yönelmektedir (Glasser, 1992). Bireylerin ruh sağlığının desteklenmesi ve iyi oluş düzeylerinin artırılması, psikolojik ihtiyaçların doyurulması ile mümkün olabilmektedir. Öz belirleme kuramında yer alan temel psikolojik ihtiyaçlar; "özerklik", "yeterlik" ve "ilişkili olma" olmak üzere üç boyutla ifade edilmektedir. Özerklik, bireyin kendi inisiyatifi ile seçim yapmasına, eylemlerde bulunmasına yönelik ihtiyacını (Andersen, 2000); yeterlik, hedefe ulaşmada etkili olma ihtiyacını (Reis, Sheldon, Gable, Roscoe ve Ryan, 2000); ilişkili olma ise, yakın çevre ile bağlantılı olmaya yönelik ihtiyacını (Cihangir Çetinkaya, 2009a) belirtmektedir. Özerklik ihtiyacı, bireyin davranışlarını ve deneyimlerini kendisinin şekillendirmesine olanak tanımaktadır. Karar verme ile eylemi gerçekleştirme sürecinde, sosyal çevreden bağımsız kararların alınabilmesi, özerklik ihtiyacının giderilmesinde aktif rol almaktadır (Deci ve Ryan, 2000). Yeterlik ihtiyac1, sosyal çevre ile etkili bir etkileşim kurabilme ve arzu edilen hedeflere ulaşabilme kapasitesini içermektedir (Deci ve Ryan, 1985a). Kendilerini yeterli hisseden bireylerin, hedeflerine başarılı bir biçimde ulaşacaklarına inandıkları gözlemlenmektedir (Williams, Gagne, Ryan ve Deci, 2002). Yakın çevre ile sağlıklı, güven verici ve yüksek doyum düzeyine sahip ilişkilerin kurulabilmesi ilişkili olma ihtiyacının giderilmesini sağlamaktadır (Deci ve Ryan, 2000). İlişkili olma ihtiyacı, karşı1ıklı güven duymayı, saygılı olmayı ve duygusal kabulü kapsamaktadır (Andersen, 2000). Ayrıca, bireylerin kişiler arası ilişkilerinde desteğe ve doyuma ulaşmalarına da olanak tanımaktadır (Ingledew, Markland ve Sheppard, 2004). Bireylerin, içsel olarak kabul edildiklerini hissetmemeleri, ilişkili olma ihtiyacının karşılanmasına engel olmaktadır. Özerklik, yeterlik ve ilişkili olma ihtiyaçlarının karşılanması bütünleşme sürecine ve iyi oluşun sağlanmasına katkıda bulunmaktadır (Ryan ve Deci, 2008; Chen ve diğ., 2015; Ryan, Sheldon, Kasser ve Deci, 1996). Cihangir-Çankaya (2009b) ile Akbağ ve Ümmet (2017) kadınların ilişkili olma ihtiyaçlarının erkeklere oranla daha yüksek düzeyde karşılandığını belirlemişlerdir. 
Psikolojik ihtiyaçların doyumu üzerine yürütülen çalışmaların daha çok; öz saygı (Jenkins, 2003), yaşam doyumu (Çivitçi, 2012; Deci ve Ryan, 2000), öznel iyi oluş (Cihangir-Çankaya, 2009a) ve cinsiyet (Cihangir-Çankaya, 2009b; Çelikkaleli ve Gündoğdu, 2005; Gündoğdu ve Yavuzer, 2012) değişkenleri üzerinde şekillendiği gözlemlenmektedir.

Temel psikolojik ihtiyaçların doyumu, farklı davranış biçimlerinin sergilenmesinde aktif rol almakta ve içinde bulunulan sosyal çevre ile kişiler arası ilişkilerde oldukça kritik bir konuma sahip olmaktadır (Sheldon, Eliot, Kim ve Kasser, 2001). Bu bağlamda, kişiler arası ilişkilerde önem arz eden öz denetim becerisi ile temel psikolojik ihtiyaçların karşılanmasının kişiler arası duygu düzenleme becerisini etkileyeceği düşünülmektedir. İlgili alan yazında duygu düzenleme kavramının (Fischer, Forthun, Pidcock ve Dowd, 2007; Karabacak ve Demir, 2017; Monteiro, Balogun ve Oratile, 2014; Ural, Güven, Sezer, Azkeskin ve Yılmaz, 2015), bilişsel duygu düzenleme kavramının (Altın, 2017; Anniko, Boersma ve Tillfors, 2018; Garnefski ve Kraaij, 2006; Sepetçi, 2019; Uyar, 2019) ele alındığı çalışmalar çeşitlilik gösterirken, kişiler arası duygu düzenleme kavramının ele alındığ çalışmalar oldukça sınırlılık göstermekte ve çalışmaların, sporcular (Debrot, Schoebi, Perrez ve Horn, 2013; Tamminen, Gaudreau, McEwen ve Crocker, 2016), çiftler (Horn ve Maercker, 2016), madde kullanım bozukluğu (Dingle, Neves, Alhadad, ve Hides, 2018), borderline kişilik bozukluğu (Dixon Gordon, Whalen, Scott, Cummins ve Stepp, 2016) üzerinde şekillendiği gözlemlenmektedir.

İlgili alan yazında konuyla ilgili yer alan çalışmaların oldukça sınırlılık göstermesi, kişiler arası duygu düzenlemeye yönelik daha çok çalışmanın yürütülmesini gerekli kılmaktadır. Mevcut çalışmalar incelendiğinde, kişiler arası duygu düzenleme ile öz denetim ve temel psikolojik ihtiyaç doyum değişkenlerinin ele alındığı herhangi bir çalışmaya ulaşılamamıştır. Araştırmanın çalışma grubunun "üniversite öğrencileri" olarak belirlenmesinde, içinde bulunulan gelişim döneminde kişiler arası ilişkilerin yoğun bir seyir izlemesi etkili olmuştur. Dolayısıyla bu yoğunluk, sağlıklı kişiler arası ilişkilerin kurulmasında etkin rol alan değişkenlerin ele alınmasını gerekli kılmaktadır. Araştırma sonucunda elde edilecek bulguların, sağlıklı kişiler arası ilişkilerin geliştirilebilmesi ve kişiler arası duygu düzenlemenin ilişkili olduğu değişkenlerin belirlenebilmesi açısından ilgili alan yazına katkı sağlayacağı düşünülmektedir.

$\mathrm{Bu}$ çalışmanın amacı; üniversite öğrencilerinin öz denetim ve temel psikolojik ihtiyaç doyum düzeylerinin, kişiler arası duygu düzenlemelerini yordama gücünü belirlemektir.

\section{YÖNTEM}

\section{1. Çalışma Grubu}

Araştırmanın çalışma grubunu, Dokuz Eylül Üniversitesi Buca Eğitim Fakültesi’nin farklı bölümlerinde öğrenimlerine devam eden, 246's1 kadın $(\% 60,2)$ ve 162'si $(\% 39,8)$ erkek olmak üzere toplam 408 üniversite öğrencisi oluşturmaktadır. Katılımcıların yaşları 18-26 yaş ( $\bar{X}=$ 21.13) aralığında yer almaktadır.

\subsection{Veri Toplama Araçları}

Araştırmada kullanılan veri toplama araçları; "Kişiler arası Duygu Düzenleme Ölçeği (KDDÖ)" (Gökdağ, Sorias, Kıran ve Ger, 2019), "Öz Denetim Ölçeği (ÖDÖ)" (Duyan ve diğerleri, 2012), "İhtiyaç Doyumu Ölçeği (İDÖ)" (Bacanlı ve Cihangir-Çankaya, 2003) ve araştırmacılar tarafından hazırlanan "Kişisel Bilgi Formu" dur.

\subsubsection{Kişiler arası Duygu Düzenleme Ölçeği (KDDÖ)}

"Kişiler arası Duygu Düzenleme Ölçeği”, Hofmann ve diğerleri (2016) tarafindan, bireylerin kişiler arası ilişkilerinde duygularını nasıl düzenlediklerini belirlemek amacıyla geliştirilmiştir. Ölçek, 5'li likert tipinde olup 20 maddeden oluşmaktadır. Ölçeğin; "sosyal model alma (social modelling)", "olumlu duyguları artırma (enhancing positive affect)", "yatıştırılma 
(soothing)" ve "bakış açısı edinme (perspective taking)" olmak üzere dört faktörü bulunmaktadır. Kișiler arası Duygu Düzenleme Ölçeği, Gökdağ, Sorias, Kıran ve Ger (2019) tarafindan Türkçeye uyarlanmıştır. Kişiler arası Duygu Düzenleme Ölçeği’nin uyarlama çalışması, 467 yetişkin üzerinde yürütülmüştür. Ölçeğin dört faktörünün Cronbach Alfa katsayısı, .81 ile .89 arasında değişmekte olup tüm maddelerin iç tutarlık katsayısı .91 olarak belirlenmiştir. Bu çalışmada ise, Kişiler arası Duygu Düzenleme Ölçeği'nin Cronbach Alfa katsayısı .90 olarak tespit edilmiştir.

\subsection{2. Öz Denetim Ölçeği (ÖDÖ)}

“Öz Denetim Ölçeği”, Rosenbaum (1980) tarafından, bireylerin öz denetim davranışlarını ve bu davranışları günlük yaşamlarında kullanma eğilimlerini ölçmek amacıyla geliştirilmiştir. Ölçek, 6'lı likert tipinde olup toplam 36 maddeden oluşmaktadır. Öz Denetim Ölçeği, Duyan ve diğerleri (2012) tarafindan Türkçeye uyarlanmıştır. Öz Denetim Ölçeği'nin uyarlama çalışması 1796 üniversite öğrencisi üzerinde gerçekleștirilmiștir. Ölçek tek boyutlu olmasına rağmen bu çalıșmada; "yenileyici (reformative)", "onarıcı (redressive)" ve "yaşantısal (experiential)" öz denetim olmak üzere üç boyut belirlenmiştir. Ölçekten alınabilecek toplam puan -108 ile +108 arasında farklılaşmaktadır. Ölçeğin Cronbach Alfa katsayısı, "yenileyici”" öz denetim boyutu için .75, "onarıcı" öz denetim boyutu için .72, "yaşantısal" öz denetim boyutu için .83 olarak belirlenmiş olup ölçeğin tamamının iç tutarlık katsayısı .80 olarak belirlenmiştir. Bu çalışmada ise, Öz Denetim Ölçeği’nin Cronbach Alfa katsayısı .96 olarak saptanmıştır. Ölçekten alınan yüksek puan, bireylerin öz denetim düzeylerinin yüksek olduğunu göstermektedir.

\subsection{3. İhtiyaç Doyumu Ölçeği (İDÖ)}

"İhtiyaç Doyumu Ölçeği”, Deci ve Ryan (1991) tarafından, bireylerin psikolojik ihtiyaçlarının doyumunu ölçmek amacıyla geliştirilmiştir. Ölçek, 7'li likert tipinde olup 21 maddeden oluşmaktadır. Ölçeğin, "özerklik (autonomy)", "yeterlik (competence)" ve "ilişkili olma (relatedness)" olmak üzere üç alt boyutu bulunmaktadır. İhtiyaç Doyumu Ölçeği, Bacanlı ve Cihangir-Çankaya (2003) tarafindan Türkçeye uyarlanmıştır. İhtiyaç Doyumu Ölçeği'nin uyarlama çalışmas 250 öğrenci üzerinde gerçekleştirilmiştir. Ölçeğin Cronbach Alfa katsayısı, "özerklik" alt boyutu için .71, "yeterlik" alt boyutu için .60, "ilişkili olma" alt boyutu için .74 olarak belirlenmiş olup ölçeğin tamamının iç tutarlık katsayısı .83 olarak belirlenmiştir. Ölçek uygulaması iki hafta arayla tekrar gerçekleştirilmiştir. Elde edilen korelasyon özerklik alt boyutu için .82 , yeterlik alt boyutu için .80 ve ilişkili olma alt boyutu için .81 olarak belirlenmiştir. Ölçeğin tamamının iç tutarlık katsayısı ise .89 olarak hesaplanmıştır. Bu çalışmada ise, İhtiyaç Doyumu Ölçeği'nin "ilişkili olma” alt boyutunun Cronbach Alfa katsayısı .94, "yeterlik” alt boyutunun Cronbach Alfa katsayısı .89, "özerklik" alt boyutunun Cronbach Alfa katsayısı .87 ve ölçeğin toplam puan üzerinden hesaplanan Cronbach Alfa katsayıs1 .95 olarak belirlenmiştir. Ölçekten alınan yüksek puan, bireylerin temel psikolojik ihtiyaçlarının karşılandığını temsil etmektedir.

\subsubsection{Kişisel Bilgi Formu}

Bireylerin kişisel bilgilerini belirlemeyi hedefleyen, araştırmacı tarafından oluşturulan formu ifade etmektedir.

\section{3. İşlem}

Araştırmaya ait veriler, 2020-2021 eğitim öğretim y1lının güz döneminde toplanmıştır. Veri toplama uygulamaları, araştırmacılar tarafından çevrimiçi ortamlard oluşturulan anket formları aracılığıyla gerçekleştirilmiştir. Katılımcılar, araştırmanın amacına yönelik bilgilendirilmiş olup uygulamalar yaklaşık olarak 20 dakika sürmüştür.

\subsection{Verilerin Analizi}

Veri analiz sürecinde ilk olarak ilgili veri setinin gerekli varsayımları karşılayıp karşılamadığı kontrol edilmiştir. Çalışmada parametrik veya parametrik olmayan analiz yöntemlerinden yararlanmaya karar vermek için normal dağılım göstergeleri (Shapiro-Wilk ile 
Kolmogorov-Smirnov normallik testleri, basıklık ve çarpıklık değerleri, Q-Q grafikleri, histogramlar) incelenmiştir. Verilerin normal dağılım gösterdiği gözlemlenmiştir. Araştırma kapsamında elde edilen verilerin analizinde, aşamalı regresyon (stepwise) analizi tekniğinden yararlanılmıştır. Verilerin analizlerinde anlamlılık değeri $\mathrm{p}<.05$ olarak kabul edilmiştir. Veriler, SPSS 24.0 paket programında değerlendirilmiştir.

\section{BULGULAR}

$\mathrm{Bu}$ kısımda betimsel istatistiklere, ölçekler arasındaki ilişkilere ve aşamalı regresyon (stepwise) analiz sonuçlarına yer verilmiştir. Katılımcıların araştırma kapsamında uygulanan ölçeklerden almış oldukları puan ortalamaları, standart sapmaları ve puan aralıkları Tablo 1'de sunulmuştur.

Tablo 1. Kişiler Arası Duygu Düzenleme Ölçeği, Öz Denetim Ölçeği, İlişkili Olma Ölçeği, Yeterlik Ölçeği ve Özerklik Ölçeği'ne İlişkin Betimsel İstatistikler

\begin{tabular}{llllllll}
\hline Ölçekler & \multicolumn{3}{c}{ Çarpıklı } & \multicolumn{3}{c}{ Basıklık } \\
\hline & $\mathrm{n}$ & $\bar{X}$ & $\mathrm{~S}_{\mathrm{d}}$ & Katsayı & $\mathrm{Se}$ & Katsayı & $\mathrm{Se}$ \\
\hline Kişiler arası Duygu Düzenleme & 408 & 77.1 & 3.8 & -1.2 & .12 & 1.2 & .24 \\
Öz Denetim & 408 & 53.2 & 4.1 & -1.3 & .12 & 1.3 & .24 \\
İlişkili Olma & 408 & 47.9 & 4.6 &,- 1.2 & .12 & .1 .2 & .24 \\
Yeterlik & 408 & 28.8 & 5.3 & -.0 .9 & .12 & 1.1 & .24 \\
Özerklik & 408 & 28.5 & 4.9 & -1.1 & .12 & 0.9 & .24 \\
\hline
\end{tabular}

Tablo 1 incelendiğinde, "Kişiler Arası Duygu Düzenleme Ölçeği” ( $\bar{X}=77.1, \mathrm{Sd}=3.8)$, "Öz Denetim Ölçeği”" ( $\bar{X}=53.2, \mathrm{Sd}=4.1)$, 'İlişkili Olma Ölçeği' ( $\bar{X}=47.9, \mathrm{Sd}=4.6)$, 'Yeterlik Ölçeği' ( $\bar{X}=28.8, \mathrm{Sd}=5.3$ ), 'Özerklik Ölçeği' ( $\bar{X}=28.5, \mathrm{Sd}=4.9)$ puan ortalamaları ve standart sapmaları görülmektedir. Ölçeklerin, çarpıklık katsayıları -0.9 ile -.1.3 ve basıklık katsayıları 0.9 ile 1.3 arasında yer almaktadır. Tabachnick ve Fidell'e (2015) göre basıklık ve çarpıklık katsayılarının \pm 1.5 olarak çıkması verilerin normal dağıldığını göstermektedir. Elde edilen değerler incelendiğinde verilerin normal dağılım varsayımını karşıladığı görülmektedir.

Üniversite öğrencilerinin kişiler arası duygu düzenleme ölçeği, öz denetim ölçeği, ilişkili olma ölçeği, yeterlik ölçeği ve özerklik ölçeği toplam ölçek puanları arasındaki ilişkiler Pearson korelasyon analizi ile değerlendirilmiş, sonuçlar Tablo 2'de sunulmuştur.

Tablo 2. Kişiler Arası Duygu Düzenleme, Öz Denetim, İlişkili Olma, Yeterlik ve Özerklik Ölçekleri Arasındaki İlişkiler

\begin{tabular}{lccccc}
\hline & $\begin{array}{c}\text { Kişiler arası Duygu } \\
\text { Düzenleme Toplam }\end{array}$ & $\begin{array}{c}\text { Öz Denetim } \\
\text { Toplam }\end{array}$ & $\begin{array}{c}\text { İlişkili } \\
\text { Olma } \\
\text { Toplam }\end{array}$ & $\begin{array}{c}\text { Yeterlik } \\
\text { Toplam }\end{array}$ & $\begin{array}{c}\text { Özerklik } \\
\text { Toplam }\end{array}$ \\
\hline $\begin{array}{l}\text { Kişiler aras1 Duygu } \\
\text { Düzenleme Toplam }\end{array}$ & 1 & $.486^{* *}$ & $.600^{* *}$ & $.545^{* *}$ & $.400^{* *}$ \\
Öz Denetim Toplam & $.486^{* *}$ & 1 & $.455^{* *}$ & $.439^{* *}$ & $.265^{* *}$ \\
İlişkili Olma Toplam & $.600^{* *}$ & $.455^{* *}$ & 1 & $.795^{* *}$ & $.732^{* *}$ \\
Yeterlik Toplam & $.545^{* *}$ & $.439^{* *}$ & $.795^{* *}$ & 1 & $.769^{* *}$ \\
Özerklik Toplam & $.400^{* *}$ & $.265^{* *}$ & $.732^{* *}$ & $.769^{* *}$ & 1 \\
\hline${ }^{*} \mathrm{p}<.05, * * \mathrm{p}<.01$ & & & & &
\end{tabular}

Tablo 2'de görüldüğü üzere üniversite öğrencilerinin kiş̧iler arası duygu düzenleme ölçeği toplam puanı ile özdenetim ölçeği toplam puanı $(\mathrm{r}=.486, \mathrm{p}<.01)$, ilişkili olma ölçeği toplam puanı, $(\mathrm{r}=.600, \mathrm{p}<.01)$, yeterlik ölçeği toplam puanı $(\mathrm{r}=.565, \mathrm{p}<.01)$ ve özerklik toplam puanı $(\mathrm{r}=.400, \mathrm{p}<.01)$ arasında pozitif yönde orta düzeyde anlamlı ilişkiler vardır. Öz denetim ölçeği toplam puanı ile ilişkili olma ölçeği toplam puanı, $(\mathrm{r}=.455, \mathrm{p}<.01)$ ve yeterlik ölçeği toplam 
puanı $(\mathrm{r}=.459, \mathrm{p}<.01)$ arasında pozitif yönde orta düzeyde anlamlı bir ilişki varken özerklik ölçeği toplam puanı $(\mathrm{r}=.265, \mathrm{p}<.01)$ arasında pozitif yönde düşük düzeyde anlamlı bir ilişki vardır. İlişkili olma ölçeği toplam puanı ile yeterlik ölçeği toplam puanı $(r=.795, p<.01)$ ve özerklik ölçeği toplam puanı $(\mathrm{r}=.732, \mathrm{p}<.01)$ arasında pozitif yönde yüksek düzeyde anlamlı ilişkiler vardır. Yeterlik ölçeği toplam puanı ile özerlik ölçeği toplam puanı $(r=.769, p<.01)$ arasında ise pozitif yönde yüksek düzeyde anlamlı ilişki vardır.

Kişiler arası duygu düzenleme ile anlamlı düzeyde ilişkileri bulunan öz denetim, ilişkili olma, yeterlik, özerklik toplam ölçek puanlarının, kişiler arası duygu düzenlemenin anlamlı birer yordayıcı olup olmadıklarını değerlendirmek amacıyla aşamalı regresyon analizi (stepwise) yapılmıştır. Analiz sonuçları Tablo 3'te ve Tablo 4'te sunulmuştur.

Tablo 3. Kişiler arası Duygu Düzenlemeye İlişkin Aşamalı Regresyon Analizi Sonuçları

\begin{tabular}{ccccc}
\hline Model & $\mathrm{R}$ & $\mathrm{R}^{2}$ & Düzeltilmiş R & Yordama Hatas1 \\
\hline 1 & .600 & .36 & .359 & 10.26 \\
2 & .643 & .417 & .414 & 9.8 \\
3 & .650 & .423 & .419 & 9.76 \\
4 & .655 & .429 & .423 & 9.72 \\
\hline
\end{tabular}

Tablo 4. Değişkenlerin B ve Beta Korelasyon Katsayıları ve Anlamlılık Düzeyleri

\begin{tabular}{ccccccc}
\hline Model & Yordayicilar & $\mathrm{B}$ & Std. Hata & $\beta$ & $\mathrm{t}$ & $\mathrm{p}$ \\
\hline 1 & Sabit & 48.44 & 1.98 & & 24.37 & .000 \\
& İlişkili Olma & .605 & .040 & .600 & 14.15 & .000 \\
2 & Sabit & 50.23 & 1.92 & & 26.161 & .000 \\
& İlişkili Olma & .482 & .043 & .478 & 11.227 & .000 \\
& Özdenetim & .078 & .012 & .268 & 6,32 & .000 \\
3 & Sabit & 49.184 & 1.984 & & 24.78 & .000 \\
& İliskkili olma & .386 & .065 & .382 & 5.97 & .000 \\
& Özdenetim & .074 & .012 & .256 & 5.97 & .000 \\
& Yeterlik & .204 & .102 & .127 & 1.9 & .000 \\
4 & Sabit & 50.392 & 2.064 & & 24.41 & 000 \\
& İliskili olma & .433 & .068 & .429 & 6.33 & .000 \\
& Özdenetim & .069 & .013 & .239 & 5.48 & .000 \\
& Yeterlik & .316 & .116 & .196 & 2.7 & .000 \\
& Özerklik & -.224 & .110 & -.128 & -2.03 & .004 \\
\hline
\end{tabular}

Birinci modelde (Bkz. Tablo 3 ve Tablo 4) ilişkili olma regresyon eşitliğine girilmiş ve kişiler arası duygu düzenleme puanının varyansın \%36'ı ilişkili olma değişkeniyle açıklanmıştır $\left(\mathrm{R}=.600, \mathrm{R}^{2}=.36\right)$. Diğer bir ifadeyle kişiler arası duygu düzenleme değişkenin en güçlü yordayıcısı ilişkili olma değişkeni olarak belirlenmiştir. Beta değerinin yönünün pozitif olması, kişiler arası duygu düzenleme ile ilişkili olma arasında pozitif yönlü bir ilişki olduğunu; kişiler arası duygu düzenleme puanı yükseldikçe ilişkili olma puanının da yükseldiğini göstermektedir.

İkinci regresyon modelinde ilişkili olma değişkeninden sonra öz denetim değişkeni modele eklenmiş ve bu değişkenin modele eklenmesi ile kişiler arası duygu düzenleme puanında açıklanan varyans \%36'dan \%41.7'e çıkmıştır $\left(\mathrm{R}=.643, \mathrm{R}^{2}=.417\right)$. Diğer bir ifade ile öz denetim değişkeninin açıklanan varyansa yaklaşık \%5.3'lük bir katkısı görülmektedir. Öz denetim değişkenine ait Beta değerinin pozitif olması, ilişkili olma, öz denetim ile kişiler arası duygu düzenleme puanı arasındaki ilişkinin pozitif yönde olduğunu, öz denetim düzeyi arttıkça kişiler arası duygu düzenleme düzeyinin de arttığını göstermektedir.

Üçüncü regresyon modelinde ilişkili olma ve özdenetim değişkenlerinden sonra modele yeterlik değişkeni eklenmiş ve bu değişkenin modele eklenmesi ile kişiler arası duygu düzenleme puanında açıklanan varyans \%41.7'den \%42.3'e yükselmiştir. $\left(\mathrm{R}=.650, \mathrm{R}^{2}=.423\right)$. Burada yeterlik değişkeninin açıklanan varyansa katkısı anlamlı olmakla birlikte, \%0.6'lık bir katkı sağlamıştır. Yeterlik değişkenine ait Beta değerinin pozitif olması, ilişkili olma, özdenetim ile 
kişiler arası duygu düzenleme puanı arasındaki ilişkinin pozitif yönde olduğunu, yeterlik düzeyi arttıkça kişiler arası duygu düzenleme düzeyinin de arttığını göstermektedir.

Dördüncü regresyon modelinde ilişkili olma, özdenetim, yeterlik değişkenlerinden sonra modele özerklik değişkeni eklenmiş ve bu değişkenin modele eklenmesi ile kişiler arası duygu düzenleme puanında açıllanan varyans $\% 42.3$ 'den $\% 42.9$ 'e yükselmiştir. $\left(\mathrm{R}=.655, \mathrm{R}^{2}=.429\right)$. Burada özerklik değişkeninin açıklanan varyansa katkısı anlamlı olmakla birlikte, \%0.06'lık düşük bir katkı sağlamıştır. Özerklik değişkenine ait Beta değerin negatif olması ilişkili olma, özdenetim, yeterlik ile kişiler arası duygu düzenleme puanı arasındaki ilişkinin ters yönde olduğunu, özerklik düzeyi arttıkça kişiler arası duygu düzenleme düzeyinin azaldığını göstermektedir.

\section{TARTIŞMA, SONUÇ VE ÖNERILER}

Bu çalışmada, öz denetim ve temel psikolojik ihtiyaç doyumunun üniversite öğrencilerinin kişiler arası duygu düzenlemeleri üzerindeki yordayıcı rolü incelenmiştir. Araştırma sonuçları incelendiğinde, kişiler arası duygu düzenleme ile öz denetim, ilişkili olma, yeterlik, özerklik toplam ölçek puanları arasında istatistiksel açıdan anlamlı ilişkiler olduğu saptanmıştır. Aşamalı regresyon analizi (stepwise) sonuçları ise, kişiler arası duygu düzenleme ile anlamlı düzeyde ilişkileri bulunan ilişkili olma, öz denetim, yeterlik, özerklik toplam ölçek puanlarının, kişiler arası duygu düzenlemenin anlamlı birer yordayıcısı olduklarını göstermektedir. Bu bağlamda, kişiler arası duygu düzenleme ile ilişkili olma, öz denetim ve yeterlik değişkenleri arasında pozitif; özerklik değişkeni ile ise negatif yönde anlamlı bir ilişki olduğu gözlemlenmektedir. Araştırma bulguları, öz denetimin ve temel psikolojik ihtiyaç doyumunun kişiler arası duygu düzenlemeye ilişkin varyansın \%42.9'unu açıkladığını; kişiler arası duygu düzenlemenin yordayıcılarının önem sırasının ilişkili olma, öz denetim, yeterlik ve özerklik olduğunu ortaya koymaktadır.

Aşamalı regresyon analizi (stepwise) sonuçları değerlendirildiğinde, kişiler arası duygu düzenlemenin en güçlü yordayıcısının İhtiyaç Doyumu Ölçeği'nin alt boyutlarından biri olan "ilişsili olma" değişkeni olduğu görülmektedir. İlişkili olma ihtiyacı, bireyin başkaları ve sosyal çevre ile ilişki kurma ihtiyacı olarak tanımlanmaktadır (Sapmaz, Doğan, Sapmaz, Temizel ve Tel, 2012). Ayrıca ilişkili olma ihtiyacı; sıcaklık, bağlanma ve ilgi deneyimlerini de bünyesinde barındırmaktadır (Vansteenkiste, Ryan ve Soenens, 2020). Mevcut araştırmadan elde edilen bulgu, kişiler arası duygu düzenleme ile ilişkili olma arasında pozitif yönde anlamlı bir ilişki olduğunu göstermektedir. Diğer bir ifadeyle, üniversite öğrencilerinin ilişkili olma düzeyleri arttıkça kişiler arası duygu düzenleme düzeyleri de artış göstermektedir. İlgili alan yazında kişiler arası duygu düzenleme ile temel psikolojik ihtiyaç doyumu ve alt boyutları arasındaki ilişkiyi doğrudan ele alan herhangi bir çalışmaya ulaşılamamaktadır. Fakat elde edilen bulguya paralel olarak duygu düzenleme stratejilerinin başkalarının duygularının anlaşılabilmesinde, başkaları ile empati kurulabilmesinde (Chew, Zain ve Hassan, 2015) ve destekleyici ilişkilerin geliştirilebilmesinde (Williams ve diğ., 2018) aktif rol aldığg ifade edilmektedir. Chacón-Cuberos, Olmedo-Moreno, Lara-Sánchez, Zurita-Ortega ve Castro-Sánchez (2019) sosyal ilişkileri güçlü olan üniversite öğrencilerinin duygularını daha kolay ifade ettiklerini belirtmektedir. İlgili alan yazında duygu düzenlemenin ilişkili olma dolayısıyla esenlik duygularını artırabileceği belirtilmektedir (La Guardia, Ryan, Couchman ve Deci, 2000; Ryan, La Guardia, Solky-Butzel, Chirkov ve Kim, 2005). Ayrıca duygu düzenlemenin sosyal ilişkilerin kalitesi ile ilişkili olduğunu belirten çalışma bulgularının da mevcut çalışmanın bulgularını destekler nitelikte olduğu söylenebilir (Eisenberg, Fabes, Guthrie ve Reiser, 2000; English ve John, 2013; Lopes ve diğ., 2011; Lopes, Salovey ve Straus, 2003).

Araştırmada, kişiler arası duygu düzenlemeyi ikinci sırada yordayan değişkenin "öz denetim" değişkeni olduğu gözlemlenmektedir. Öz denetim, bireyin benliği ile dünya arasında 
ideal bir uyuma ulaşması için benliği değiştirme ve uyarlama kapasitesini ifade etmektedir (Rothbaum, Weisz ve Snyder, 1982). Ayrıca, bireyin düșüncelerini, duygularını, dürtülerini ve davranışlarını kontrol etmeye veya geçersiz kılmaya yönelik yeteneğini de içermektedir (Gailliot ve diğerleri, 2007). Dolayısıyla öz denetim, hem bireye hem de bireyin yakın çevresinde yer alan bireylere olumlu etkisi bulunan duygusal kalıplarla ilişkilendirilmektedir (Evers, 2018). Mevcut araştırmadan elde edilen bulgu, öz denetim ile kişiler arası duygu düzenleme arasında pozitif yönde anlamlı bir ilişki olduğunu göstermektedir. Diğer bir ifadeyle, üniversite öğrencilerinin öz denetim düzeyleri arttıkça kişiler arası duygu düzenleme düzeyleri de artış göstermektedir. Baumeister (2002) duygu düzenlemenin, bireyin kendini düzenleyebilme (self-control) yollarından bir tanesi olduğunu ifade etmektedir. Bu durum, öz denetim ile duygu düzenlemenin yakından ilişkili olabileceğini düşündürmektedir. Buna rağmen ilgili alan yazında yer alan çalışmalar, öz denetimin kişiler arası duygu düzenleme ile ilişkili olup olmadığını açıkça göstermemektedir. Ayrıca ilgili alan yazında kişiler arası duygu düzenleme ile öz denetim arasındaki ilişkiyi doğrudan ele alan herhangi bir çalışmaya ulaşılamamaktadır. Mevcut bulguya paralel olarak Verhofstadt (2017) çalışmasında öz denetimin, uyarlanabilir duygu düzenleme stratejileri ile anlamlı ve olumlu yönde ilişkili olduğunu tespit etmiştir. Tangney ve diğerleri (2004), ideal duygusal tepkileri, daha iyi yakın ilişkileri ve kişiler arası becerileri yüksek öz denetim ile ilişkilendirmektedir. Mevcut bulguların aksine Tice ve Bratslavsky (2000) duygu düzenlemenin, öz denetim davranışlarını engelleyebileceğini ve zaman yönetimi, dürtü kontrolü gibi alanlarda sergilenen öz denetim davranışlarının başarısızlıkla sonuçlanabileceğini belirtmektedir. Bununla birlikte Wenzel, Rowland ve Kubiak (2020) duygu düzenlemenin, özdenetim ve iyi oluş arasında aracı bir rol üstlenmediğini ifade etmektedir. İlgili alan yazında yer alan araştırma bulgularının farklılaşmasında, araştırmanın sınırlılıkları, araştırmaya katılan bireylerin demografik bilgileri ile kültürel farklılıkları etken olabilmektedir. Dolayısıyla bu durum, konu ile ilgili daha çok araştırmanın yürütülmesini gerekli kılmaktadır.

Araştırmada, kişiler arası duygu düzenlemeyi üçüncü sırada yordayan değişkenin "yeterlik" değişkeni olduğu gözlemlenmektedir. Yeterlik ihtiyacı, bireylerin çevreyle etkileşimlerinde kendilerini etkili hissetme arzularını (Deci ve Ryan, 2000; Ryan ve Deci, 2017) ve potansiyellerini kullanmalarını içermektedir. Birey, yeteneklerini ortaya koyarak ve genişleterek yeterlik ihtiyacını giderebilmektedir. Mevcut araştırmadan elde edilen bulgu, yeterlik ile kişiler arası duygu düzenleme arasında pozitif yönde anlamlı bir ilişki olduğunu göstermektedir. Diğer bir ifadeyle, üniversite öğrencilerinin yeterlik düzeyleri arttıkça kişiler arası duygu düzenleme düzeyleri de artı̧̧ göstermektedir. Çevre, bireylerin ihtiyaçlarının karşılanmasını desteklediğinde, bireyler çevre hakkında olumlu bir değerlendirmeye sahip olmaktadırlar. Bu olumlu değerlendirme ile birlikte bireyler, sorunlar karşısında kendilerini yeterli hissetmekte ve duygularını etkin bir şekilde düzenleyebilmektedirler (Shalchi ve Shahna, 2018). Erken dönem yaşantılarında temel psikolojik ihtiyaçları karşılanmış bireylerin, duygu düzenleme becerilerine sahip oldukları ifade edilmektedir (Lopes ve diğ., 2005). Yeterlik ihtiyac1 karşılanmayan bireylerin ise zor durumlar ile baş etmede zorlandıkları, dolayısıyla duygu düzenleme güçlüğü ile karşılaşma olasılıklarının daha yüksek olduğu belirtilmektedir (Emery, Heath ve Mills, 2015). Mevcut bulguya paralel olarak Emery ve diğerleri (2015) kendine zarar verme davranışları sergilediklerini bildiren üniversite öğrencileriyle gerçekleştirdikleri araştırmada, üniversite öğrencilerinin temel psikolojik ihtiyaçlarının giderilme düzeylerinin düşük olduğunu; duygu düzenleme güçlüklerinin ise yüksek olduğunu tespit etmişlerdir. Bireylerin duygu düzenlemelerine yönelik algılarının, yeterlik ihtiyaçlarının karşılanmasına ilişkin değerlendirmeleri ile yakından ilişkili olduğu görülmektedir. Yeterlik ihtiyaçlarının karşılanmaması, duygu düzenleme sürecinin de olumsuz etkilenmesine neden olmaktadır.

Araştırmada, kişiler arası duygu düzenlemeyi dördüncü sırada yordayan değişkenin “özerklik” değişkeni olduğu gözlemlenmektedir. Ancak, özerklik değişkeninin kişiler arası duygu düzenlemeyi yordamadaki katkısının oldukça düşük olduğu görülmektedir. Özerklik, bireylerin eylemlerini ve davranışlarını yönetebilme hâlini tanımlamaktadır (Ryan ve Deci, 2000). Özerklik ihtiyacının giderilmesi, bireylerin seçimlerini kendilerinin gerçekleştirdiklerini, davranışları 
üzerinde kontrol sahibi olduklarını ve davranışlarının sorumluluğunu üstlendiklerini göstermektedir (Chirkov, Kim, Ryan ve Kaplan, 2003). Williams ve diğerleri (2001), özerkliğin davranış bağlamında ele alınmasında seçim ve irade kavramlarının önemini vurgulamaktadırlar. Mevcut araştırmadan elde edilen bulgu, özerklik ile kişiler arası duygu düzenleme arasında negatif yönde anlamlı bir ilişki olduğunu göstermektedir. Diğer bir ifadeyle, üniversite öğrencilerinin özerklik düzeyleri arttıkça kişiler arası duygu düzenleme düzeyleri düşüş göstermektedir. İlgili alan yazında özerklik ihtiyacının üç temel psikolojik ihtiyaç arasında yer alan yeterlik ve ilişkili olma ihtiyacına oranla daha çok öneme sahip olduğunu belirten çalışmalar yer almaktadır (Deci ve Ryan, 1985b; Ryan, 1995). Temel psikolojik ihtiyaçların giderilmesi ile, bireylerin duygularının farkında olması ve duygularını daha net bir şekilde ifade edebilmesi beklenmektedir (Emery ve diğ., 2015). Bu durum, özerkliğin kişiler arası duygu düzenleme ile yakından ilişkili olabileceğini düşündürmektedir. Buna rağmen ilgili alan yazında, özerkliğin kişiler arası duygu düzenleme ile ilişkisini doğrudan ele alan herhangi bir çalışmaya ulaşılamamış, dolayısıyla mevcut araştırma bulguları karşılaştırılamamıştır. Harvey ve Retter (2002), özerklik ihtiyacının cinsiyete göre farklılık göstermediğini belirlemiştir. CihangirÇankaya (2009b) ise iyi olmanın en güçlü yordayıcısının özerklik ihtiyacı olduğunu, bu ihtiyacı sırasıyla ilişkili olma ve yeterlik ihtiyacının izlediğini tespit etmiştir. Ryan ve diğerleri (1996) ile Reis ve diğerleri (2000), bireylerin özerklik, yeterlik ve ilişkili olma ihtiyaçlarının doyum düzeyleri arttıkça olumlu duygularının arttığını, olumsuz duygularının ise azaldığını tespit etmişlerdir. Ayseli (2019), çalışmasında özerklik, yeterlik ve ilişkili olma ihtiyaçları karşılanmış bireylerin, duygu düzenleme güçlüklerinin azaldığını ve dolaylı olarak kendilerini affetme eğilimlerinin arttığını belirlemiştir. Shalchi ve Shahna (2018) ise üniversite öğrencileri ile gerçekleştirdikleri çalışmada, temel psikolojik ihtiyaçların doyumu ile aile içi iletişim arasındaki ilişkinin belirlenmesinde duygu düzenleme güçlüğünün aracı rolünü ele almışlardır. Çalışmada, temel psikolojik ihtiyaçları giderilen bireylerin duygu düzenleme güçlüklerinin düşük olduğu, aile içi iletişime ise olumlu katkıda bulunduğu tespit edilmiştir. Dolayısıyla ilgili alan yazında yer alan bu bulguların, mevcut bulgu ile çeliştiği söylenebilmektedir (Ayseli, 2019; Emery ve diğerleri, 2015; Shalchi ve Shahna, 2018). Bireylerin eylemlerini kendi iradeleri ile düzenleme ihtiyac1 özerklik ihtiyacı olarak değerlendirilmektedir. Bireyler eylemlerini, kendi ilgilerine ve değer yargılarına göre şekillendirmektedirler. Bu bağlamda, özerkliğin şekillenmesinde özerkliğin algılanma biçiminin etkisi olduğu söylenebilmektedir. Özerklik, yeterlik ve ilişkili olma gibi evrensel ihtiyaçların giderilmesi içsel motivasyonla birlikte bireyin içinde bulunduğu sosyal çevreye ve kültüre de bağlı olmaktadır. $\mathrm{Bu}$ durum katılımcıların bireysel farklarının değerlendirilmesinin yanı sıra içinde bulunulan sosyal çevrenin ve kültürün değerlendirilmesini gerekli kılmaktadır. Schimmack, Radhakrishnan, Oishi, Dzokoto ve Ahadi (2002), bireyci kültür yapısının, özerkliğin güçlendirilmesini ve duyguların ifade edilmesini desteklediğini ifade etmektedir. Toplulukçu kültür yapısı ise kişisel amaçları ve özerkliği desteklememekte, daha çok toplum normlarına önem vermektedir. Dolayısıyla mevcut çalışma bulgusunun ilgili alan yazında yer alan bulgularla çelişmesinde kültürel yapının ve özerkliğin algılanma biçiminin etkili olduğu düşünülmektedir.

Araştırma bulguları değerlendirildiğinde, öz denetim ile temel psikolojik ihtiyaç doyumunun alt boyutları olan ilişkili olma, yeterlik, özerklik değişkenlerinin üniversite öğrencilerinin kişiler arası duygu düzenlemelerini yordadığı gözlemlenmektedir. Araştırmanın bulgularının değerlendirilmesinde araştırma sınırlılıklarının da dikkate alınması gerekmektedir. Araştırmada elde edilen bulgular, Dokuz Eylül Üniversitesi Buca Eğitim Fakültesi öğrencilerinden elde edilen verilere dayanmaktadır. Araştırmada belirli bir örneklem grubu ile çalışılması nedeniyle araştırma bulguları, kapsamlı bir genellemeye olanak tanıyamamaktadır. Dolayısıyla daha geniş ve farklı demografik özelliklere sahip örneklem gruplarıly araştırmaların yürütülmesi, bulguların genellenebilmesi açısından yararlı olacaktır.

Araştırmadan ele edilen bulgular, üniversite öğrencilerinin öz denetim becerilerinin geliştirilmesine ve temel psikolojik ihtiyaçların karşılanmasına yönelik hizmetlerin kişiler arası duygu düzenlemelerini artırmada etkili olacağını düşündürmektedir. Dolayısıyla araştırma 
bulguları, üniversitelerin psikolojik danışma birimlerine ve ilgili birimlerde sunulan psikolojik danışma hizmetlerine dikkatleri çekmektedir. Buna rağmen pek çok üniversite ve bu üniversitelere bağlı fakülte, öğrencilerine yeterli ve işlevsel bir psikolojik danışmanlık hizmeti sağlayamamaktadır. Konuyla ilgili yürütülecek çalışmalar, özdenetim ve duygu düzenleme sorunları ile psikolojik danışmanlık birimine başvuran üniversite öğrencilerine etkili bir psikolojik danışma hizmeti sunulmasına da yardımcı olacaktır. $\mathrm{Bu}$ bağlamda üniversite öğrencilerinin öz denetim ve kişiler arası duygu düzenleme becerilerinin geliştirilmesine yönelik psiko-eğitim programlarının geliştirilmesi ve uygulanması oldukça önem kazanmaktadır.

Yakın ilişkiler kurma ve özerklik ihtiyacı, beliren yetişkinlik dönemine özgü gelişim görevleri arasında yer almaktadır. Yakın ilişkiler bağlamında kişiler arası duygu düzenleme süreci ve öz denetim oldukça kritik bir konumda yer almaktadır. Dolayısıyla kişiler arası duygu düzenleme, öz denetim ve temel psikolojik ihtiyaç doyum değişkenlerinin ele alınması hem yakın ilişkiler hem de beliren yetişkinlik döneminin kapsamı ile ilgili daha çok bilgi sahibi olunmasına da katk1 sağlayacaktır.

Öz denetim ile temel psikolojik ihtiyaç doyumunun üniversite öğrencilerinin kişiler arası duygu düzenleme düzeyleri üzerindeki etkisinin ortaya koyulduğu bu çalışmada, üniversite ögrencilerinin kişiler arası duygu düzenleme düzeyleri sınırlı sayıda değişkenle ele alınmıştır. Araştırma bulguları, öz denetimin ve temel psikolojik ihtiyaç doyumunun kişiler arası duygu düzenlemeye ilişkin varyansın \%42.9'unu açıkladığını ortaya koymakta, açıklanamayan varyans, kişiler arası duygu düzenlemenin farklı yordayıcılarının olduğuna dikkatleri çekmektedir. Bu bağlamda kişiler arası duygu düzenlemenin farklı değişkenlerle ele alınmasının ilgili alan yazına katk1 sağlayacağı düşünülmektedir. Buna ek olarak, ülkemizde ve dünyada üniversite öğrencilerinin kişiler arası duygu düzenleme düzeyleriyle ilgili çalışmaların oldukça sınırlılık göstermesi dikkatleri çekmektedir. Beliren yetişkin nüfusunun yoğun olduğu Türkiye'de yürütülecek yeni çalışmalar, ilgili konunun desteklenmesine yönelik ihtiyacın giderilmesine de katk1 sağlayacaktır.

\section{KAYNAKÇA}

Akbağ, M. ve Ümmet, D. (2017). Predictive role of grit and basic psychological needs satisfaction on subjetive well-being for young adults. Journal of Education and Practice, 8(26), 127135 .

Akkuş Çutuk, Z. (2020). Üniversite öğrencilerinde özdenetim ile internet bağımlılığı ilişkisi. Trakya Eğitim Dergisi, 10(3), 854-863.

Altın, M. (2017). Amatör düzeyde futbol oynayan sporcuların bilişsel duygu düzenleme ve saldirganlık düzeyleri arasındaki ilişkinin incelenmesi (Yayınlanmamış Yüksek Lisans Tezi). Maltepe Üniversitesi Sosyal Bilimler Enstitüsü. İstanbul.

Andersen, S. (2000). Fundamental human needs: making social cognition relevant. Psychological Inquiry, 11(4), 269-276.

Anniko, M.K., Boersma, K. ve Tillfors, M. (2018). Investigating the mediating role of cognitive emotion regulation in the development of adolescent emotional problems. Nordic Psychology, 70(1), 3-16.

Ayseli, C. (2019). Temel psikolojik ihtiyaçlar ve kendini bağışlama: duygu düzenleme güçlüğü, suçluluk ve utanç duygularının aracılık rollerinin incelenmesi (Yayınlanmamış Yüksek Lisans Tezi). Maltepe Üniversitesi Sosyal Bilimler Enstitüsü. İstanbul.

Bacanlı, H. ve Cihangir-Çankaya, Z. (2003). İhtiyaç doyumu ölçeği uyarlama çalışması. VII. Ulusal Psikolojik Danışma ve Rehberlik Kongresi Bildiri Özetleri. Malatya, İnönü Üniversitesi. Ankara: Pegem Akademi. 
Baumeister, R. F. (2002). Yielding to temptation: Self-control failure, impulsive purchasing, and consumer behaviour. Journal of Consumer Research, 28(4), 670-676.

Baumeister, R. F. ve Alquist, J. L. (2009). Is there a downside to good self-control?. Self and Identity, 8(2-3), 115-130.

Bosse, T., Pontier, M. ve Treur, J. (2010). A compuational model based on gross' emotion regulation theory. Cognitive Systems Research, 11(3), 211-230.

Chacón-Cuberos, R., Olmedo-Moreno, E. M., Lara-Sánchez, A. J., Zurita-Ortega, F. ve CastroSánchez, M. (2019). Basic psychological needs, emotional regulation and academic stress in university students: a structural model according to branch of knowledge. Studies in Higher Education, 1-15. doi:10.1080/03075079.2019.1686610

Chen, B., Vansteenkiste, M., Beyers, W., Boone, L., Deci, E. L., Van der Kaap Deeder, J., ve diğerleri (2015). Basic psychological need satisfaction, need frustration, and need strength across four cultures. Motivation and Emotion, 39(2), 216-236.

Chew, B. H., Zain, A. M. ve Hassan, F. (2015). The relationship between the social management of emotional intelligence and academic performance among medical students. Psychology, Health \& Medicine 20(2), 198-204. doi:10.1080/ 13548506.2014.913797

Chirkov, V. I., Ryan, R.M., Kim, Y. ve Kaplan, U. (2003). Differentiating autonomy from individualism and independence: A self-determination theory perspective on internalization of cultural orientations and well-being. Journal of Personality and Social Psychology, 84(1), 97-110.

Cihangir-Çankaya, Z. (2009a). Özerklik desteği, temel psikolojik ihtiyaçların doyumu ve öznel iyi olma: Öz-belirleme kuram1. Türk Psikolojik Danışma ve Rehberlik Dergisi, 4(31), 2331.

Cihangir-Çankaya, Z. (2009b). Öğretmen adaylarında temel psikolojik ihtiyaçların doyumu ve iyi olma. Türk Ĕgitim Bilimleri Dergisi, 7(3), 691-711.

Coan, J. (2011). The social regulation of emotion. Decety, J. ve Cacioppo, J. T. (Ed). Handbook of social neuroscience içinde (s. 614-623). New York: Oxford University Press.

Çelikkaleli, Ö. ve Gündoğdu, M. (2005). Eğitim fakültesi öğrencilerinin psikolojik ihtiyaçları. Eğitim Fakültesi Dergisi, 6(9), 43-53.

Çivitçi, A. (2012). Üniversite öğrencilerinde genel yaşam doyumu ve psikolojik ihtiyaçlar arasındaki ilişkiler. Çukurova Üniversitesi Sosyal Bilimler Enstitüsü, 21(2), 321-336.

Debrot, A., Schoebi, D., Perrez, M. ve Horn, A. B. (2013). Touch as an interpersonal emotion regulation process in couples' daily lives: The mediating role of psychological intimacy. Personality and Social Psychology Bulletin, 39(10), 1373-1385. doi:10.1177/0146167213497592

Deci, E. L. ve Ryan, R. M. (1985a). Intrinsic motivation and self-determination in human behavior. New York: Plenum Press.

Deci E. L. ve Ryan, R. M. (1985b). The general causality orientations scale: self determination in personality. Journal Of Research In Personality, 19(2), 109-134.

Deci, E. L. ve Ryan, R. M. (1991). A motivational approach to self: Integration in personality. Dienstbier, R. (Ed.). Nebraska symposium on motivation: Perspectives on motivation içinde (s. 237-288). University of Nebraska Press.

Deci, E. L. ve Ryan, R. M. (2000). The "what" and "why" of goal pursuits: human needs and the self determination of behavior. Psychological Inquiry, 11(4), 227-268. 
DeLisi, M, Beaver, K. M., Vaughn, M. G., Trulson, C. R., Kosloski, A. E., Alan, J., ve diğerleri. (2010). Personality, gender, and self-control theory revisited: results from a sample of institutionalized juvenile delinquents. Applied Psychology in Criminal Justice, 6(1), 3146.

Dingle, G. A., Neves, D. D. C., Alhadad, S. S. ve Hides, L. (2018). Individual and interpersonal emotion regulation among adults with substance use disorders and matched controls. British Journal of Clinical Psychology, 57(2), 186-202. doi:10.1111/bjc.12168

Dixon Gordon, K. L., Haliczer, L. A., Conkey, L. C. ve Whalen, D. J. (2018). Difficulties In Interpersonal Emotion Regulation: Initial Development And Validation Of A SelfReport Measure. Journal of Psychopathology and Behavioral Assessment, 40(3), 528- 549.

Dixon Gordon, K. L., Whalen, D. J., Scott, L. N., Cummins, N. D. ve Stepp, S. D. (2016). The main and interactive effects of maternal interpersonalemotion regulation and negative affect on adolescent girls'borderline personality disorder symptoms. Cognitive Therapy and Research, 40(3), 381-393.

Duyan, V., Gülden, Ç. ve Gelbal, S. (2012). Öz-denetim ölçeği-ÖDÖ: Güvenilirlik ve geçerlilik çalışması. Toplum ve Sosyal Hizmet, 23(1), 25-38.

Eisenberg, N., Fabes, R. A., Guthrie, I. K. ve Reiser, M. (2000). Dispositional emotionality and regulation: Their role in predicting quality of social functioning. Journal of Personality and Social Psychology, 78(1), 136-157.

Emery, A. A., Heath, N. L. ve Mills, D. J. (2015). Basic psychological need satisfaction, emotion dysregulation, and non-suicidal self-1njury engagement in young adults: An application of self-determination theory. Journal of Youth and Adolescence, 45(3), 612-623.

English, T. ve John, O. P. (2013). Understanding the social effects of emotion regulation: The mediating role of authenticity for individual differences in suppression. Emotion, 13(2), $314-329$.

Evers, C. (2018). Emotion regulation and self-control: Implications for health behaviors and wellbeing. de Ridder, D., Adriaanse, M. ve Fujita, K. (Ed.). Routledge international handbooks. The Routledge international handbook of self-control in health and wellbeing içinde (s. 317-329). Routledge/Taylor \& Francis Group.

Fischer, J. L., Forthun, L. F., Pidcock, B. W. ve Dowd, D. A. (2007). Parent relationships, emotion regulation, psychosocial maturity and college student alcohol use problems. Journal of Youth and Adolescence, 36(7), 912-926. doi:10.1007/s10964-006-9126-6

Friese, M. ve Hofmann, W. (2009). Control me or I will control you: impulses, trait self-control, and the guidance of behavior. Journal of Research in Personality, 43(5), 795-805.

Gailliot, M.T., Baumeister, R. F., DeWall, C. N., Maner, J. K., Plant, E. A., Tice, D. M., ve diğerleri. (2007). Self-control relies on glucose as a limited energy source: Willpower is more than a metaphor. Journal of Personality and Social Psychology, 92(2), 325-336. doi: 10.1037/0022-3514.92.2.325

Garnefski, N. ve Kraaij, V. (2006). Relationships between cognitive emotion regulation strategies and depressive symptoms: A comparative study of five specific samples. Personality and Individual Differences, 40(8), 1659-1669.

Glasser, W. (1965). Reality therapy. New York: Harper \& Row Publisher.

Glasser, W. (1992). The quality school: managing students without coercion. New York: Harperperennial.

Goleman, D. (2000). İşbaşında duygusal zeka. (Çev. H. Balkara). İstanbul: Varlık Yayınları. 
Gökdağ, G., Sorias, O., Kıran, S. ve Ger, S. (2019). Kişiler arası duygu düzenleme ölçeğinin Türkçeye uyarlanması ve psikometrik özelliklerinin incelenmesi. Türk Psikiyatri Dergisi, 30(1), 57-66.

Gross, J. J. (1998). The emerging field of emotion regulation: An integrative review. Review of General Psychology, 2(3), 271-99.

Gross, J. J. (2015). Emotion regulation: Current status and future prospects. Psychological Inquiry, 26(1), 1-26.

Gross, J. J. ve John, O. P. (2003). Individual differences in two emotion regulation processes: 1mplications for affect, relationships and well-being. Journal of Personality and Social Psychology, 85(2), 348-362.

Gündoğdu R. ve Yavuzer, Y. (2012). Eğitim fakültesi öğrencilerinin öznel iyi oluş ve psikolojik ihtiyaçlarının demografik değişkenlere göre incelenmesi. Mehmet Akif Ersoy Üniversitesi Eğitim Fakültesi Dergisi, 12(23), 115-131.

Harvey, V. S. ve Retter, K. (2002). Variation of gender differences between children and adolsecents on the four basic psychological needs. International Journal of Reality Therapy, 21(2), 33-36.

Hofmann, S. G., Carpenter, J. K. ve Curtiss, J. (2016). Interpersonal emotion regulation questionnaire (IERQ): Scale development and psychometric characteristics. Monographs of the Society for Research in Child Development, 40(3), 341-56.

Horn, A. B. ve Maercker, A. (2016). Intra- and interpersonal emotion regulation and adjustment symptoms in couples: The role of co-brooding and co-reappraisal. BMC Psychology, 4(1), 51 .

Inglewed, D., Markland, D. ve Sheppard, K. (2004). Personality and self determination of exercise behavior. Personality and Individual Differences, 36(8), 1921- 1932.

Jenkins, S. (2003). Gender and self- determination in sexual motivation (Unpublished Doctoral Thesis). University of Rochester. Rochester.

Johnson, J. A. ve Ostendorf, F. (1993). Clarification of the five-factor model with the abridged big five dimentional circumplex. Journal of Personality and Social Psychology, 3(63), 563576.

Karabacak, A. ve Demir, M. (2017). Özerklik, bağlanma stilleri, bilinçli farkındalık ve duygu düzenleme arasındaki ilişkilerin incelenmesi. Bayburt Eğitim Fakültesi Dergisi, 12(23), 412-431.

Kızıltaş, A. (2019). Üniversite öğrencilerinin öz denetim, stresle başa çıkma ve sosyal destek algilar ile alkol ve madde kullanma riskleri arasındaki ilişsilerin incelenmesi (Yayınlanmamış Doktora Tezi). Hacettepe Üniversitesi Sosyal Bilimler Enstitüsü. Ankara.

Kim, N. S. ve Lee, K. E. (2012). Effects of self-control and life stress on smart phone addiction of university students. Journal of the Korea Society of Health Informatics and Statistics, 37(2), 72-83.

La Guardia, J. G., Ryan, R. M., Couchman, C. ve Deci, E. L. (2000). Within-person variation in security of attachment: A self-determination theory perspective on attachment, need fulfillment, and well-being. Journal of Personality and Social Psychology, 79(3), 367-384.

Lopes, P. N., Nezlek, J. B., Extremera, N., Hertel, J., Ferna'ndez-Berrocal, P., Schu“tz, A., ve diğerleri. (2011). Emotion regulation and the quality of social interaction: Does the ability to evaluate emotional situations and identify effective responses matter? Journal of Personality, 79(2), 429-467. 
Lopes, P. N., Salovey, P., Côté, S., Beers, M. ve Petty, R. E. (2005). Emotion regulation abilities and the quality of social interaction. Emotion, 5(1), 113-118. doi: 10.1037/15283542.5.1.113

Lopes, P. N., Salovey, P. ve Straus, R. (2003). Emotional intelligence, personality, and the perceived quality of social relationships. Personality \& Individual Differences, 35(3), 641658.

MacDonald, K. (1995). Evolution, the five- factor model and levels of personality. Journal of Personality, 63(3), 525-567.

Marroquín, B. (2011). Interpersonal emotion regulation as a mechanism of social support in depression. Clinical Psychology Review, 31(8), 1276-1290.

Mayer, J., Salovey, P. ve Caruso, D. (2000). Models of emotional intelligence. Handbook of intelligence. New York: Cambridge University Press.

Monteiro, N. M., Balogun, S. K. ve Oratile, K. N. (2014). Managing stress: the influence of gender, age and emotion regulation on coping among university students in Botswana. International Journal of Adolescence and Youth, 19(2), 153-173.

Niven, K., Garcia, D., van der Löwe, I., Holman, D. ve Mansell, W. (2015). Becoming popular: interpersonal emotion regulation predicts relationship formation in real life social networks. Frontiers in Psychology, 6, 1-11.

Reis, H., Sheldon, K., Gable, S., Roscoe, J. ve Ryan, R. (2000). Daily well-being: the role of autonomy, competence and relatedness. Personality and Social Psychology Bulletin, 26(4), 419-435.

Rosenbaum, M. (1980). A Schedule for assessing self-control behaviors: Preliminary findings. Behavior Therapy, 11(1), 109-21.

Rosenbaum, M. (1993). The three functions of self-control behaviour: redressive, reformative and experiential. Work ve Stress, 7(1), 33-46. doi:10.1080/02678379308257048

Rothbaum, F., Weisz, J. R. ve Snyder, S. S. (1982). Changing the world and changing the self: A two-process model of perceived control. Journal of Personality and Social Psychology, 42(1), 5-37.

Ryan, R. (1995). Psychological needs and the facilitation of integrative processess. Journal of Personality, 63(3), 397-428.

Ryan, R. ve Deci, E. (2000). Self-determination theory and the facilitation of intrinsic motivation, social development and well- being. American Psychologist, 55(1), 68-78.

Ryan, R. ve Deci, E. L. (2008). Self-determination theory and the role of basic psychological needs in personality and the organization of behavior. John, O. P., Robins, R. W. ve Pervin, L. A. (Ed.). Handbook of personality: Theory and research içinde (s. $654-678)$. New York: The Guilford Press.

Ryan, R. M. ve Deci, E. L. (2017). Self-determination theory: Basic psychological needs in motivation, development, and wellness (10rd ed.). New York: The Guilford Press.

Ryan, R. M., La Guardia, J. G., Solky-Butzel, J., Chirkov, V. ve Kim, Y. (2005). On the interpersonal regulation of emotions: Emotional reliance across gender, relationships, and culture. Personal Relationships, 12(1), 146-163.

Ryan, R. M., Sheldon, K. M., Kasser, T. ve Deci, E. L. (1996). All goals are not created equal: an organizmic perspective on the nature of goals and their regulation. Gollwitzer, P. M. ve Bargh, J. A. (Ed.). The psychology of action: Linking cognition and motivation to behavior içinde (s. 7-26). New York: Guilford Press. 
Sapmaz, F., Doğan, T., Sapmaz, S., Temizel, S. ve Tel, F. D. (2012). Examining predictive role of psychological need satisfaction on happiness in terms of self-determination theory. Procedia-Social and Behavioral Sciences, 55, 861-868.

Schimmack, U., Radhakrishnan, P., Oishi, S., Dzokoto, V. ve Ahadi, S. (2002). Culture, personality ve subjective well-being integrating process models of life satisfaction. Journal of Personality and Social Psychology, 82(4), 582- 593.

Sepetçi, M. (2019). Yetişkinlerde bilişsel duygu düzenleme, kişiler arası ilişki problemleri, sürekli öfke ve öfke ifade tarzları arasındaki ilişkiler (Yayınlanmamış Yüksek Lisans Tezi). Maltepe Üniversitesi Sosyal Bilimler Enstitüsü. İstanbul.

Shalchi, B. ve Shahna, E. M. (2018). Relationship of family functioning, satisfaction of basic psychological needs and depression considering the mediatory role of emotion regulation difficulty. Hormozgan Medical Journal, 22(1), 52-61.

Sheldon, K. M., Elliot, A. J., Kim, Y. ve Kasser, T. (2001). What is satisfying about satisfying events? Testing 10 candidate psychological needs. Journal of Personality and Social Psychology, 80(2), 325-333.

Tabachnick, B. G. ve Fidell, L. S. (2015). Çok değişkenli istatistiklerin kullanımı (Çev. M. Baloğlu). Ankara: Nobel Yayın Dağıtım.

Tamminen, K.A., Gaudreau, P., McEwen, C. E. ve Crocker, P. E. (2016). Interpersonal emotion regulation among adolescent athletes: A Bayesian multilevel model predicting sport enjoyment and commitment. Journal of Sport \& Exercise Psychology, 38(6), 541-555. doi:10.1123/jsep.2015-0189

Tangney, J. P., Baumeister, R. F. ve Boone, A. L. (2004). High self-control predicts good adjustment, less pathology, better grades, and interpersonal success. Journal of Personality, 72(2), 272- 322 .

Tatnell, R., Kelada, L., Hasking, P. ve Martin, G. (2014). Longitudinal analysis of adolescent NSSI: The role of intrapersonal and interpersonal factors. Journal of Abnormal Child Psychology, 42(6), 885-896.

Thompson, R. A. (1994). Emotion regulation: A theme in search of definiton. Monographs of the Society for Research in Child Development, 59(2), 25-52.

Tice, D. M. ve Bratslavsky, E. (2000). Giving in to feel good: The place of emotion regulation in the context of general self-control. Psychological Inquiry, 11(3), 149-159. doi: 10.1207/S15327965PLI1103_03

Ural, O., Güven, G., Sezer, T., Azkeskin, K. E. ve Y1lmaz, E. (2015). Okul öncesi dönemdeki çocukların bağlanma biçimleri ile sosyal yetkinlik ve duygu düzenleme becerileri arasındaki ilişkinin incelenmesi. Hacettepe Üniversitesi Sağllk Bilimleri Fakültesi Dergisi, 1, 589-598.

Uyar, M. (2019). Beliren yetişkinlik dönemindeki bireylerin psikolojik iyi oluş düzeylerini yordamada bağlanma tarzları ve bilişsel duygu düzenlemenin rolünün incelenmesi (Yayınlanmamış Yüksek Lisans Tezi). Maltepe Üniversitesi Sosyal Bilimler Enstitüsü. İstanbul.

Vansteenkiste, M., Ryan, R. M. ve Soenens, B. (2020). Basic psychological need theory: Advancements, critical themes, and future directions. Motivation and Emotion, 44(2), 131.

Verhofstadt, N. (2017). Control yourself!: The relationships between self-control, emotion regulation strategies, and social interaction anxiety (Master Thesis). Tilburg University Social and Behavioural Sciences. Tilburg. 
Wenzel, M., Rowland, Z. ve Kubiak, T. (2020). How mindfulness shapes the situational use of emotion regulation strategies in daily life. Cognition and Emotion, 34(5), 1-15.

Williams, G., Gagne, M., Ryan, R. ve Deci, E. (2002). Facilitating autonomous motivation for smoking cessation. Health Psychology, 21(1), 40-50.

Williams, G., Minicucci, D., Koudies, R., Levesque, C., Chirkov, V., Ryan, R., ve diğerleri. (2001). Self determination, smoking, diet and health. Health Education Research, 17(5), 512-521.

Williams, W. C., Morelli, S. A., Ong, D. C. ve Zaki, J. (2018). Interpersonal emotion regulation: Implications for affiliation, perceived support, relationships, and well-being. Journal of Personality And Social Psychology, 115(2), 224-254. doi:10.1037/pspi0000132

Yarkın, E. (2014). Temel psikolojik ihtiyaçların karşılanma düzeyinin ilişki doyum ve yaşam doyum düzeyine katkısının incelenmesi (Yayınlanmamış Yüksek Lisans Tezi). Arel Üniversitesi Sosyal Bilimler Enstitüsü. İstanbul.

Zaki, J. (2020). Integrating empathy and interpersonal emotion regulation. Annual Review of Psychology, 4(71), 517-540.

Zaki, J. ve Williams, W. C. (2013). Interpersonal emotion regulation. Emotion, 13(5), 803-810.

\section{EXTENDED ABSTRACT}

Individuals need to express their feelings, thoughts and behaviors through verbal and nonverbal methods throughout their lives. Feelings have a complex structure; it makes it difficult to be defined, understood and to meet the need to express emotions. Mayer et al. (2000) define emotion as "responses with physiological, biological and cognitive elements that individuals give to situations in their social environment". Emotions form the basis of interpersonal relationships and are at the center of daily life. Functional expression of emotions is possible with the ability to regulate emotions. The concept of emotion regulation refers to the internal or external processes responsible for observing, evaluating and changing emotions (Thompson, 1994). While internal processes are the process of organizing one's own emotions through interpersonal relationships; external processes refer to the process of regulating the emotions of others (Dixon Gordon et al., 2018).

Understanding the emotion regulation process better is only possible by obtaining information about the mechanisms underlying the behavior. At this point, the concept of selfcontrol emerges. The ability to change individuals' behaviors (Tangney et al., 2004) and adapt (Duyan et al., 2012) is defined as the concept of self-control. Self-control; It has three dimensions: redressive, reformative and experiential self-control. Redressive self-control, dealing with negative moods; reformative self-control, regulatory behaviors to be exhibited to achieve balance; experiential self-control includes new experiences that have been open. Individuals can shape their emotions and behaviors according to their basic psychological needs. Basic psychological needs in self-determination theory; it is expressed in three dimensions as 'autonomy', 'competence' and 'relatedness'. Autonomy refers to the individual's need to choose and act on his own initiative (Andersen, 2000); competence, the need to be effective in achieving the goal (Reis et al., 2000); relatedness indicates the need to be connected with the social environment (Cihangir-Çetinkaya, 2009a). Satisfaction of basic psychological needs takes an active role in the display of different behavioral patterns and has a very critical position in interpersonal relations with the current social environment (Sheldon et al., 2001). In this context, the aim of this study is; to determine the predictive power of university students' self-control and basic psychological need satisfaction levels on interpersonal emotion regulation. 
The study group of the study consists of 408 university students, 246 women $(60.2 \%)$ and $162(39.8 \%)$ men, who study in different departments of Dokuz Eylül University Buca Faculty of Education. The ages of the participants are in the range of 18-26 and the average age is 21.13. To collect data, Interpersonal Emotion Regulation Questionnaire (Hofmann et al., 2016; Gökdağ et al., 2019), Self-Control Scale (Rosenbaum, 1980; Duyan et al., 2012), Basic Psychological Need Satisfaction Scale (Deci \& Ryan, 1991; Bacanlı \& Cihangir-Çankaya, 2003) and personal information form were used.

During the data analysis process, it was first checked whether the data set met the necessary assumptions. It was observed that the data showed normal distribution. In the analysis of the data; stepwise analysis technique was used. The data were evaluated in the SPSS 24.0 package program. When the results of the study were examined, it was found that there were statistically significant relationships between interpersonal emotion regulation and self-control, relatedness, competence, and autonomy total scale scores. A stepwise regression analysis was conducted to evaluate whether the total scale scores of the relevant variables were significant predictors of interpersonal emotion regulation. Research findings show that self-control and basic psychological need satisfaction explain $42.9 \%$ of the variance related to interpersonal emotion regulation between individuals; it reveals that the relative order of importance predictors of interpersonal emotion regulation are relatedness, self-control, competence and autonomy.

In this study, the predictive role of self-control and basic psychological need satisfaction on interpersonal emotion regulation of university students was examined. In the study, it was found that there is a positive significant relationship between relatedness to interpersonal emotion regulation. In the relevant literature, there is no study that directly addresses the relationship between interpersonal emotion regulation and basic psychological need satisfaction and its subdimensions. In the study, it was determined that there is a positive significant relationship between self-control and interpersonal emotion regulation. The limitations of the research, the demographic information and cultural differences of the individuals participating in the research may be effective in the differentiation of the research findings in the relevant literature. In the study, it was found that there is a positive and significant relationship between competence and interpersonal emotion regulation. Failure to meet the competence needs causes the emotion regulation process to be negatively affected. Finally, in the study, a significant negative relationship was found between autonomy and interpersonal emotion regulation. However, it is seen that the contribution of autonomy variable in predicting interpersonal emotion regulation is quite low. Meeting universal needs such as autonomy, competence, and relatedness depends on both intrinsic motivation and the individual's social environment and culture. This situation suggests that the contradiction between the findings of the current study and the findings in the literature is due to the cultural structure difference.

The findings of the study suggest that services aimed at developing self-control skills of university students and meeting their basic psychological needs will be effective in increasing interpersonal emotion regulation. In this context, the development and implementation of psychoeducation programs for the development of self-control and interpersonal emotion regulation skills of university students becomes very important. The need for close relationships and autonomy are among the developmental tasks specific to emerging adulthood. Interpersonal emotion regulation and self-control are at a critical position in the context of close relationships with their social dimension. Therefore, addressing the variables of interpersonal emotion regulation, self-control and basic psychological need satisfaction will contribute to gaining more information about both close relationships and the scope of the emerging adulthood period. It is noteworthy that studies on interpersonal emotion regulation levels of university students in our country and in the world are quite limited. New studies to be carried out in our country, which has a large emerging adult population, will contribute to the support of the relevant issue. 